\title{
On two closely related funnel-web spider species, Agelena orientalis C.L. Koch, 1837, and A. labyrintbica (Clerck, 1757) (Aranei: Agelenidae)
}

\section{Ава близких вида пауков-воронкопрядов Agelena orientalis C.L. Koch, 1837 и A. labyrintbica (Clerck, 1757) (Aranei: Agelenidae)}

\author{
Mykola M. Kovblyuk, Zoya A. Kastrygina \\ Н.М. Ковбцюк, 3.А. Кастрыгина
}

Zoology Department, V.I. Vernadsky Taurida National University, 4 Yaltinskaya str., Simferopol 95007, Ukraine. E-mail: kovblyuk@mail.ru; zoiac_21@mail.ru

Кафедра зоологии Таврического национального университета им. В.И.Вернадского, ул. Ялтинская 4, Симферополь 95007, Украина.

KEY WORDS: spiders, Agelena, redescriptions, spatial distribution, phenology, Crimea.

КЛЮЧЕВЫЕ СЛОВА: пауки, Agelena, переописания, ландшафтное распределение, фенология, Крым.

ABSTRACT. Redescriptions of two closely related species Agelena orientalis C.L. Koch, 1837 and A. labyrinthica (Clerck, 1757) are provided, based on specimens from Crimea, continental Ukraine and Abkhazia (West Caucasus). Crimea is supposed to be the northernmost point of $A$. orientalis distribution. Comparative illustrations, diagnoses, spatial distribution, seasonal dynamics of activity for both species are presented.

РЕЗЮМЕ. По экземплярам из Крыма, материковой части Украины и Абхазии переописаны близкие и трудно различимые виды Agelena orientalis C.L. Koch, 1837 и A. labyrinthica (Clerck, 1757). Крым - самая северная часть ареала A. orientalis. Для обоих видов приведены сравнительные рисунки, дифференциальный диагноз, распределение по ландшафтным зонам Крыма и сезонная динамика активности половозрелых особей.

\section{Introduction}

Genus Agelena Walckenaer, 1805, contains 68 species from the Old World [Platnick, 2011]. So far, three species have been reported from Crimea [Kovblyuk, 2004a]: A. labyrinthica (Clerck, 1757), A. orientalis C.L. Koch, 1837, and A. gracilens C.L. Koch, 1841. Agelena taurica Thorell, 1875, was described from Crimea (Sudak and Simferopol) and Sarepta (=Krasnoarmeisk near of Volgograd, Russia) [Thorell, $1875 \mathrm{ab}$. This species description is the result of misidentification of females of $A$. orientalis and male of $A$. gracilens [Blauwe, 1980: 26]. The latter species was recently transferred to the genus Allagelena Zhang, Zhu \& Song, 2006 [Platnick, 2011]. Thus, only two Agelena species are formally recorded from Crimea at present.
Correct identification of Agelena species in Crimea is problematic for a number of reasons. Little-known species $A$. orientalis can be easy misidentified with a well-known species, $A$. labyrinthica. Although many illustrations and descriptions were made for both species [see Platnick, 2011], only two papers contained comparative drawings [Blauwe, 1980; Levy, 1996]. A. orientalis is an ecological vicariant of $A$. labyrinthica [cf. Guseinov et al., 2005: 155], so only one of these species could possibly be distributed within the small Crimean peninsula. The previous records have been reviewed because of possible confusion of these species. Surprisingly, the presence of both closely related species in Crimea has been confirmed.

The aim of article is to provide redescriptions of $A$. orientalis and $A$. labyrinthica, and also to provide information about spatial distribution and seasonal dynamics of activity of adults in Crimea.

\section{Material and Methods}

Specimens of $A$. orientalis and A. labyrinthica from Crimea, and from continental Ukraine and Caucasus, were recently collected by the authors and their friends and colleagues. Material treated herein was shared between personal collection of E.M. Zhukovets in Minsk, Belarus (EMZ) and collection of Zoology Department, V.I. Vernadsky Taurida National University, Simferopol, Ukraine (TNU).

Drawings were made using both reflecting and transmitted light microscopes. Illustrations of epigynes were made after maceration in $20 \% \mathrm{KOH}$ solution. Photographs were taken in dishes of different sizes with paraffin at the bottom. Specimens were photographed using an Olympus Camedia E-520 camera attached to an Olympus SZX16 stereomicroscope at the Zoological Museum, University of Turku. Digital images were 
montaged using a "CombineZM" image stacking software.

Legs and palps segments were measured after their separation from the cephalothorax. All measurements are in mm: minimum-maximum; a figure in brackets represents the average.

The following abbreviations of morphological terms adobe from Guseinov et al. [2005] with additions (Ef, $F d$ and $P e$ ) and have been used in the text and figures.

Spines: a - apical; d - dorsal; pl — prolateral; $\mathrm{rl}$ retrolateral; v — ventral. Eyes: AM — anterior median eyes; AL - anterior lateral eyes; PM - posterior median eyes; PL - posterior lateral eyes. Male palp: Co - conductor; Em - embolus; Eo - outgrowth of embolus; $E t$ - tip of embolus; $M a$ - median apophysis; $\mathrm{Pa}$ - patellar apophysis; $\mathrm{Ra}$ - retrolateral tibial apophysis; $R v$ - retroventral tibial apophysis. Epigyne: $A a$ - accessorial arm; $E f$ - epigynal fovea; $E o-$ epigynal opening; $F d$ - fertilization duct; $P e$ - posterior edge of epigynal fovea; $R e$ - receptaculum; $R t$ - receptaculum's tube; $S r$ - sac of receptaculum.

\section{Species survey}

Agelena orientalis C.L. Koch, 1837

Figs 1-3, 7-9, 13-15, 19-20, 23-24, 27.

A. o.: Brignoli, 1976: 563, f. 43 ( + , elevated from subspecies). A. labyrinthica o.: de Blauwe, 1980: 16, f. 26-29 (ठㅇ).

A. o.: Levy, 1996: 86, f. 4-8 ( $\left.\sigma^{7}+\right)$.

For a complete list of references see Platnick [2011].

RECORDS FROM CRIMEA. Thorell, 1875ab - sub Agalena taurica sp.n. [pro parte - females only: Blauwe, 1980]; Fausek, 1909 and Spassky, 1927 — sub A. taurica Thor.; Charitonov, 1932, 1936 - sub A. similis Keis. var. taurica Thorell, 1875; Tyshchenko, 1971 — sub A. taurica; Mikhailov, 1997, 1998; Kovblyuk, 2002 - sub Agelena gracilens taurica Thorell, 1875; Kovblyuk, 2004a; Kovblyuk \& Kukushkin, 2007; Kovblyuk et al., $2008 \mathrm{ab}$.

MATERIAL. UKRAINE. Crimea: Chernomorsky Distr.: 2 우 (EMZ), Tarhankut Cape, 9.08.1997, D.V. Gluhov; Feodosiya Distr.: $5 \mathrm{O}^{7} \sigma^{7}$ (TNU-1821/4), Karadag Nature Reserve, 07.2003, O.V. Kukushkin; 1 (TNU-1793/2), same place, Syuryu-Kaya Mt. steppe, 10.10.2003, M.K.; 1 (TNU-1825/3), same place, kordon Verhnie Trasy, 27.07.2003, O.V. Kukushkin; 1 q (TNU-1824/4), same place, 08.2003, O.V. Kukushkin; $1 \sigma^{7}$ (TNU-2018/1), same place, 1-15.07.2004, O.V. Kukushkin; $1 \sigma^{7}$ (TNU-2009/4), same place, 15-30.07.2004, O.V. Kukushkin; $1 \sigma^{7}$ (TNU-2020/1), same place, Biological station, 6-10.08.2004, O.V. Kukushkin; 1 ㅇ (TNU2003/2), same place, Karadag Valley, 1-15.09.2004, O.V. Kukushkin; 1 q (TNU-1993/3), same place, 16-31.10.2004, O.V. Kukushkin; 1 क (TNU-2000/3), same place, 14.11.2004, O.V. Kukushkin; 1 ○ (TNU-1985/5), same place, 6-12.07.2005, M.K.; 1 o (TNU-1968/1), same place, 27.08.-10.09.2005, O.V. Kukushkin; $2 \sigma^{7} \sigma^{7}$ (TNU-2308/4), same place, Biological station, 1-31.07.2006, O.V. Kukushkin; 1 (TNU-2303/1), same place, Magnitnyi Mt. Range, 19.09.2006, O.V. Kukushkin; 1 ㅇ (TNU-2298/3), same place, Svyataya Mt., 15.10.2006, O.V. Kukushkin; 2 of (TNU2409/2), same place, Biological station, 3.07.2007, A.A. Nadolny; 1 (TNU-2378/1), same place, Gyaur-Cheshme, 3.07.2007, M.A. Kovaleva; 1 ㅇ (TNU-2398/1), same place, kordon Verhnie Trasy, 4-5.07.2007, M.K.; 3 ऽ $\sigma^{7}, 4$ 우 (TNU), same place, Kara-Agach Mt., 19.06.2008, Z.A. Kastrygina; $1 \sigma^{7}$ (TNU-2721/3), same place, Karadag Valley, pitfalls, 2-21.07.2008, A.A. Nadolny; 2 우 (TNU2566/5), same place, 21-22.07.2008, A.A. Nadolny; Lenin Distr.: 1 ㅇ (EMZ), Kerch Peninsula, Opuk Mt., 2.07.1996, M.K.; $\underline{\text { Saky }}$ Distr.: 4 우 (EMZ), Yevpatoriya, 3.08.1997, M.K.; 1 ㅇ (EMZ),
Yevpatoriya, 24.08.1997, M.K.; Sevastopol Distr.: 2 OO (TNU), Sarych Cape, 1.07.1997, M.K.; $2 \sigma^{7} \sigma^{7}, 2$ 우 (EMZ), Sarych Cape, 2.07.1997, M.K.; 1 O (TNU), Sarych Cape, 16-17.06.2000, O.V. Kukushkin; 2 우 (EMZ), env. Balaklava, 22.08.1998, M.K.; 1 우 (EMZ), same place, 23.08.1998, M.K.; 1 (EMZ), env. Rodnoe Vill., Uppa River Valley, 12-13.06.1999, O.V. Kukushkin; Sudak Distr.: $2 \sigma^{\top} \sigma^{\top}, 4$ 우 (EMZ, TNU), Meganom Cape, 15.07.1996,

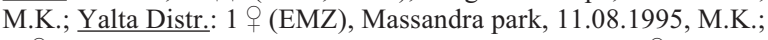
1 (TNU), env. Nikita Vill., 18.09.1999, M.K.; 1 q (TNU), Vasyl'evka Vill., 9-10.09.1999, M.K.; 2 o+ (TNU-1312/1), env. Nikita Vill., pitfalls, 9-16.07.2000, M.K.; 3 우 (TNU-1313/1), same place, 16-23.07.2000, M.K.; 1 O $^{7}, 3$ 우 (TNU-1314/1), same place, 23-30.07.2000, M.K.; 3 우 (TNU-1315/2), same place, 31.07.-11.08.2000, M.K.; 1 क (TNU-1343/5), same place, 2231.07.2001, M.K.; 1 क (TNU-1344/3), same place, 31.07.11.08.2001, M.K.; 1 क (TNU-1345/3), same place, 11-24.08.2001, M.K.; 1 ㅇ (TNU-1347/2), same place, 4-14.09.2001, M.K.; 9 우 (TNU-2269/5, 2271/1), Martyan Cape Reserve, 22.07.2000, M.K.; 1 o (TNU-2355/3), same place, 12.07.2007, M.K.; 1 q (TNU2411/5), same place, 29.09.2007, M.K.

DIAGNOSIS. A. orientalis is very similar to $A$. labyrinthica. We found no good differences (hiatus) in coloration, measurements or spination. Male palps and epigynes also extremely similar. Two species can be easily separated by the shape the tip of embolus in prolateral view (straight in $A$. orientalis and curved in A. labyrinthica - cf. Figs. $3 \& 6,7 \& 10,20 \& 22$ ), by size and shape of epigynal fovea (cf. Figs. 13-15 \& $16-18,27 \& 28$ ) and the position of receptacles (cf. Figs. 15 \& 18). Also minor differences between males can be found in the shape of retroventral tibial apophysis (cf. Figs. $2 \& 5,8 \& 11,19 \& 21$ ), in the shape of patellar apophysis (cf. Figs. $1 \& 4,2 \& 5,9 \& 12,19 \&$ $21,23-24 \& 25-26)$ and in length of some leg segments (male metatarsus III in A. orientalis 6.5-8.4, in A. labyrinthica 5.1-6.2; male femur IV in A. orientalis 7.1-9.0, in A. labyrinthica 6.0-6.9).

DESCRIPTION. Males $(n=15)$ and females $(n=15)$. Measurements $\left(\sigma^{\top} / q\right)$ : total length 11.0-13.6 (9.8) / 10.2-17.7 (13.0); carapace 5.1-6.8 (5.9) / 5.0-6.8 (6.0) long, 3.8-5.0 (4.4) / 3.5-5.0 (4.4) wide. Diameters of eyes and distances between them: AM 0.20-0.28 (0.26) / 0.26-0.33 (0.29), AL 0.18-0.28 (0.24) / 0.24-0.30 (0.27), PM 0.15-0.21 (0.20) / 0.21-0.24 (0.22), ĐL $0.20-0.24(0.22) / 0.21-0.27$ (0.25), AM-AM 0.09$0.15(0.13) / 0.10-0.14$ (0.11), AM-AL 0.08-0.16 (0.12) / 0.08-0.14 (0.10), PM-PM 0.21-0.33 (0.25) / $0.20-0.30(0.25)$, PM-PL $0.16-0.30(0.24) / 0.20-$ $0.30(0.25)$, AM-PM 0.22-0.30 (0.26) / 0.21-0.28 (0.25), AL-PL 0.06-0.14 (0.10) / 0.06-0.10 (0.08). Distances between anterior eyes and margin of clypeus: AM-clypeus 0.62-0.86 (0.74) / 0.52-0.82 (0.70), ALclypeus $0.44-0.58(0.77) / 0.36-0.52(0.46)$. Length of palp segments (male/female): femur 1.8-2.4 (2.2) / $1.8-2.4(2.1)$, patella $0.6-1.0(0.8) / 0.8-1.0(0.9)$, tibia $0.4-0.6(0.5) / 0.8-1.2(1.0)$, tarsus 2.0-2.6 (2.4) / 2.0 2.5 (2.3). Length of leg segments (male/female) as in Table 1.

Cheliceral teeth $\left(\sigma^{7} / 9\right)$ : anterior - 3/3; posterior 3 or 4 ( 1 of 15 males has one chelicera with 3 teeth and one with 4 teeth) / 3 or 4 ( 2 of 15 females have both chelicerae with 4 teeth; 4 of 15 females have one chelicera with 4 teeth and one with 3 teeth). 

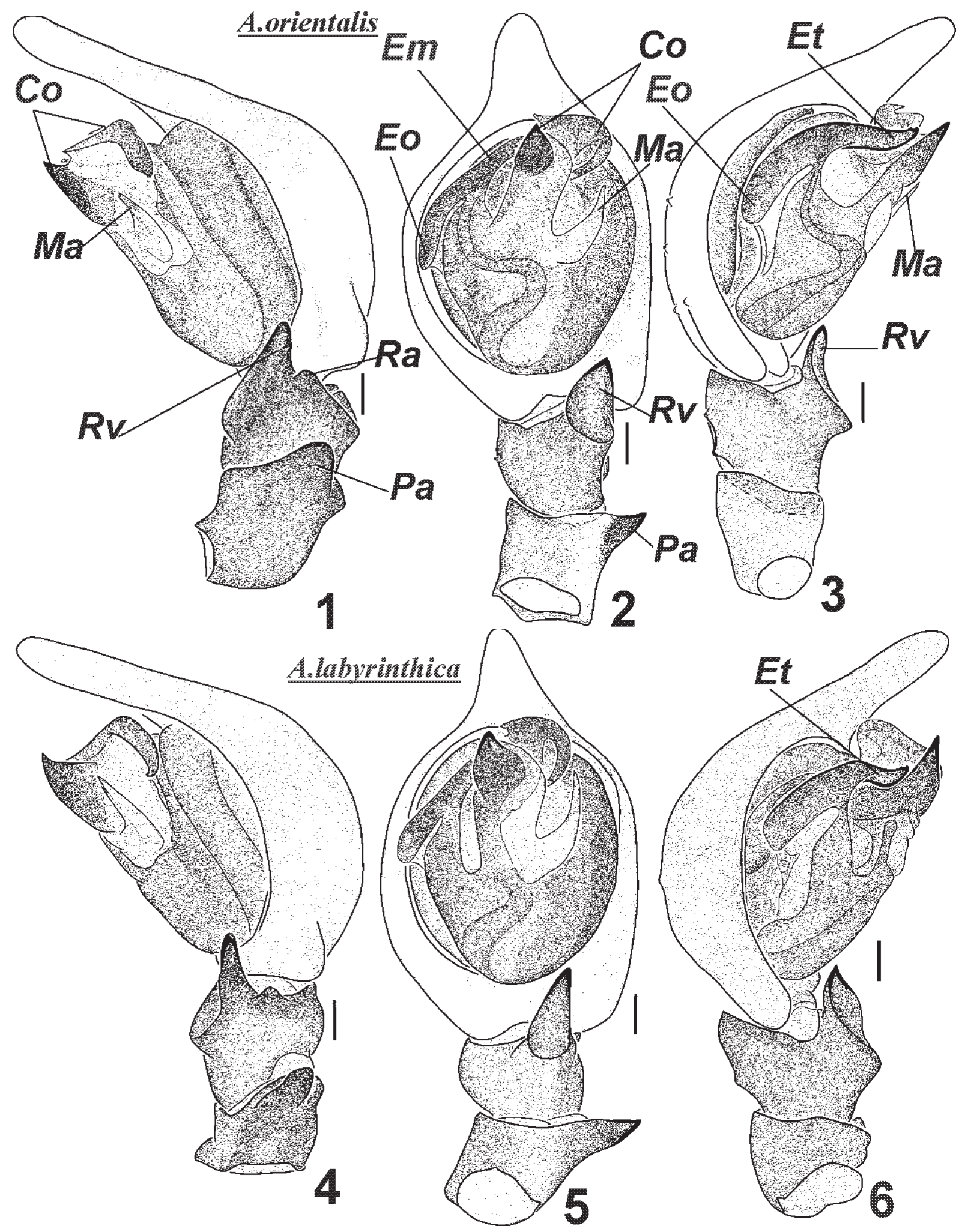

Figs 1-6. Male palps of Agelena orientalis (1-3) and A.labyrinthica (4-6): 1, 4 - retrolateral view; 2, 5 - ventral view; 3, 6 prolateral view. Scale bars $0.1 \mathrm{~mm}$.

Рис. 1-6. Пальпы самцов Agelena orientalis (1-3) и A.labyrinthica (4-6): 1, 4 - ретролатерально; 2, 5 — вентрально; 3, 6 пролатерально. Масштаб 0,1 мм. 
Table 1. Length of leg segments of Agelena orientalis C.L. Koch (male/female). Таблица 1. Длина сегментов ног Agelena orientalis C.L. Koch (самец/самка).

\begin{tabular}{|l|l|l|l|l|l|l|}
\hline Leg & \multicolumn{1}{c|}{ Femur } & \multicolumn{1}{c|}{ Patella } & \multicolumn{1}{c|}{ Tibia } & \multicolumn{1}{c|}{ Metatarsus } & \multicolumn{1}{c|}{ Tarsus } & \multicolumn{1}{c|}{ Total } \\
\hline \multirow{2}{*}{ I } & $6.3-7.8(7.2) /$ & $2.0-2.6(2.3) /$ & $5.6-7.4(6.6) /$ & $6.8-8.7(8.0) / 4.4$ & $2.9-3.6(3.2) /$ & $23.6-30.1(27.3) /$ \\
& $4.6-6.3(5.6)$ & $1.8-2.4(2.2)$ & $3.8-5.2(4.7)$ & $6.2(5.4)$ & $2.2-2.6(2.4)$ & $16.7-22.6(20.3)$ \\
\hline \multirow{2}{*}{ II } & $6.0-7.8(7.0) /$ & $1.9-2.5(2.2) /$ & $5.1-6.8(6.0) /$ & $6.6-8.5(7.7) / 4.2-$ & $2.8-3.4(3.1) /$ & $22.4-28.1(26.0) /$ \\
& $4.4-6.0(5.5)$ & $1.7-2.4(2.1)$ & $3.4-4.8(4.2)$ & $5.9(5.1)$ & $2.0-2.4(2.2)$ & $17.1-21.1(19.2)$ \\
\hline \multirow{2}{*}{ III } & $5.7-7.4(6.6) /$ & $1.7-2.3(2.0) /$ & $4.4-6.0(5.3) /$ & $6.5-8.4(7.6) / 4.2-$ & $2.5-3.2(2.9) /$ & $20.8-27.4(24.4) /$ \\
& $4.2-5.8(5.2)$ & $1.6-2.2(1.9)$ & $3.1-4.2(3.8)$ & $6.0(5.2)$ & $1.8-2.3(2.1)$ & $14.9-20.4(18.2)$ \\
\hline \multirow{2}{*}{ IV } & $7.1-9.0(8.0) /$ & $1.8-2.4(2.1) /$ & $5.8-7.0(6.7) /$ & $9.0-11.7(10.1) /$ & $3.3-4.1(3.6) /$ & $27.0-34.4(30.6) /$ \\
& $5.5-7.1(6.5)$ & $1.8-2.4(2.1)$ & $4.2-5.7(5.2)$ & $6.2-8.6(7.6)$ & $2.3-2.9(2.7)$ & $20.0-26.6(24.2)$ \\
\hline
\end{tabular}
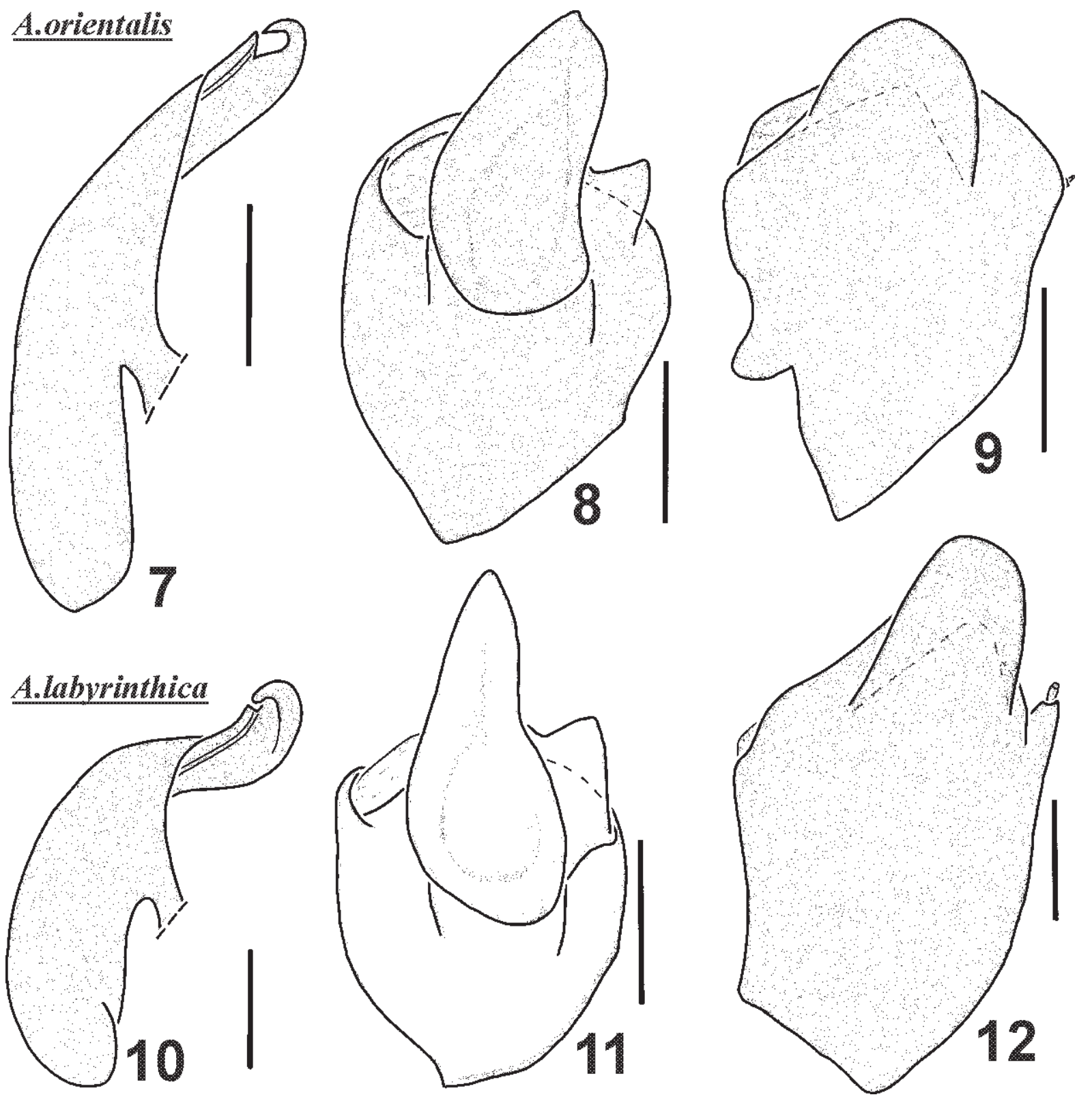

Figs 7-12. Details of male copulatory organs of Agelena orientalis (7-9) and A.labyrinthica (10-12): 7, 10 - embolus, prolateral view; 8, 11 - tibia, ventral view; 9, 12 - patella, retrolateral view. Scale bars $0.1 \mathrm{~mm}$.

Рис. 7-12. Детали копулятивных органов самцов Agelena orientalis (7-9) и A.labyrinthica (10-12): 7, 10 — эмболюс, пролатерально; 8, 11 - голень пальпы, вентрально; 9, 12 - колено пальпы, ретролатерально. Масштаб 0,1 мм. 
Table 2. Length of leg segments of Agelena labyrinthica (Clerck) (male/female). Таблица 2. Длина сегментов ног Agelena labyrinthica (Clerck) (самец/самка).

\begin{tabular}{|l|l|l|l|l|l|l|}
\hline Leg & \multicolumn{1}{|c|}{ Femur } & \multicolumn{1}{c|}{ Patella } & \multicolumn{1}{c|}{ Tibia } & \multicolumn{1}{c|}{ Metatarsus } & \multicolumn{1}{c|}{ Tarsus } & \multicolumn{1}{c|}{ Total } \\
\hline \multirow{2}{*}{ I } & $4.8-6.2(5.6) /$ & $1.7-2.0(1.8) /$ & $4.2-5.6(4.9) /$ & $5.0-6.8(5.9) / 3.4$ & $2.3-3.0(2.7) /$ & $18.3-23.6(20.8) /$ \\
& $4.1-5.2(4.6)$ & $1.7-2.0(1.8)$ & $3.2-4.4(3.8)$ & $4.7(4.1)$ & $1.8-2.4(2.1)$ & $14.2-18.6(16.5)$ \\
\hline \multirow{2}{*}{ II } & $4.7-6.0(4.5) /$ & $1.7-2.0(1.8) /$ & $3.8-5.0(4.5) /$ & $4.8-6.3(5.4) / 3.3-$ & $2.2-2.8(2.5) /$ & $17.3-22.2(20.0) /$ \\
& $3.9-5.0(4.5)$ & $1.6-2.0(1.8)$ & $3.0-3.8(3.5)$ & $4.6(3.9)$ & $1.6-2.2(1.9)$ & $13.3-17.6(15.2)$ \\
\hline \multirow{2}{*}{ III } & $4.8-6.2(5.3) /$ & $1.5-1.8(1.6) /$ & $3.8-4.5(4.0) /$ & $5.1-6.2(5.7) / 3.4-$ & $2.3-2.5(2.4) /$ & $17.6-21.0(19.1) /$ \\
& $3.8-5.0(4.4)$ & $1.4-2.0(1.7)$ & $2.7-4.0(3.2)$ & $4.8(4.0)$ & $1.6-2.0(1.8)$ & $13.0-17.0(15.0)$ \\
\hline \multirow{2}{*}{ IV } & $6.0-6.9(6.4) /$ & $1.6-1.9(1.7) /$ & $4.8-5.8(5.3) /$ & $7.4-9.0(8.0) / 5.2-$ & $2.9-3.4(3.1) /$ & $22.9-26.9(24.6) /$ \\
& $4.8-6.2(5.6)$ & $1.6-2.0(1.8)$ & $3.7-4.8(4.3)$ & $6.9(6.2)$ & $1.6-2.6(2.3)$ & $17.4-22.4(20.1)$ \\
\hline
\end{tabular}
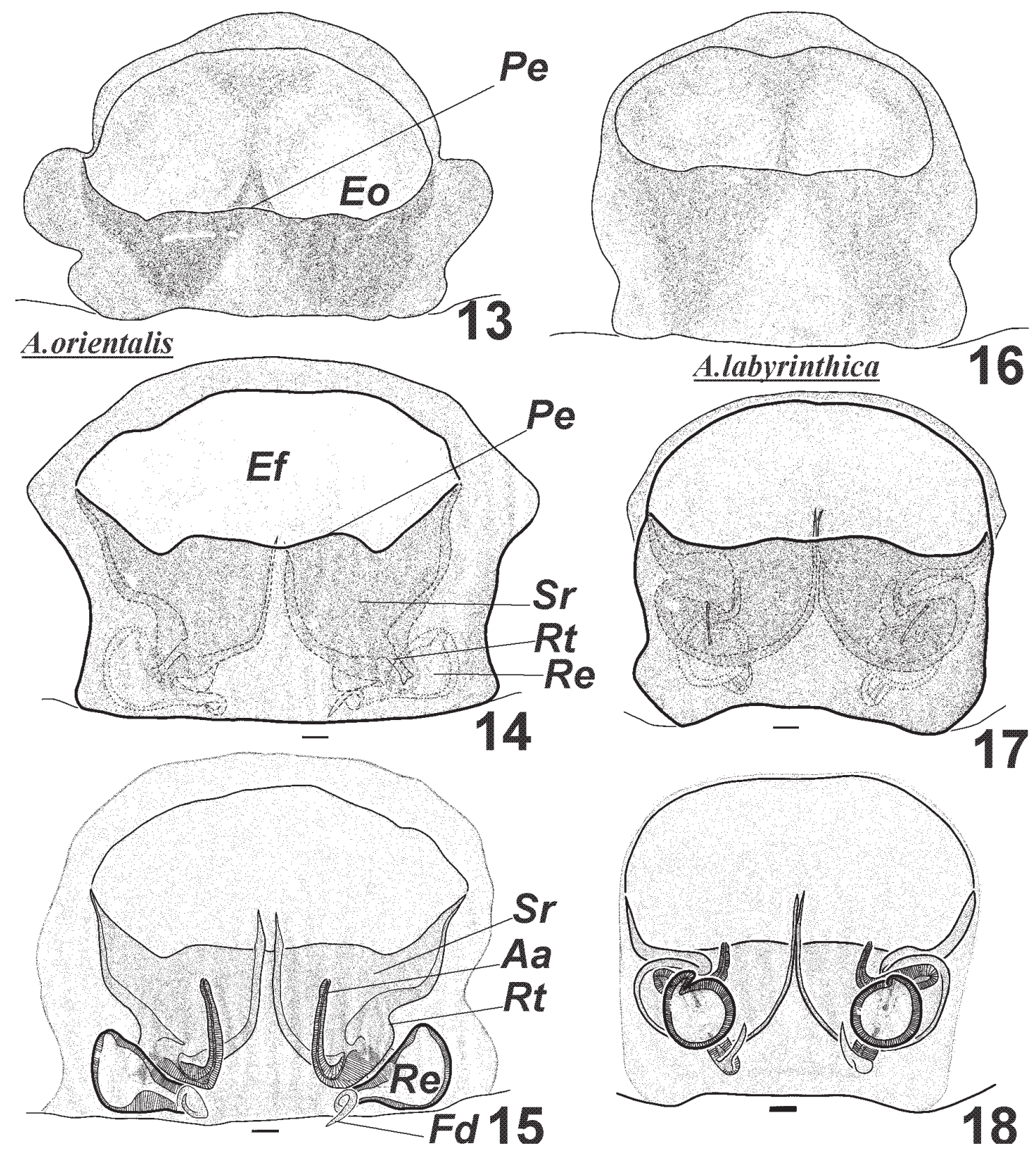

Figs 13-18. Epigynes of Agelena orientalis (13-15) and A.labyrinthica (16-18): 13, 16 — ventral view; 14, 17 — ventral view after maceration; 15,18 - dorsal view after maceration. Scale bars $0.1 \mathrm{~mm}$.

Рис. 13-18. Эпигины Agelena orientalis (13-15) и A.labyrinthica (16-18): 13, 16 — вентрально; 14,17 - вентрально после мацерации; 15, 18 - дорсально после мацерации. Масштаб 0,1 мм. 
Coloration yellow with peculiar dorsal pattern on abdomen.

Male palp: Figs 1-3, 7-9, 19-20, 23-24; epigyne: Figs 13-15, 27.

TYPE LOCALITY. Greece: Nauplia [Levy, 1996].

DISTRIBUTION. Mediterranean to Central Asia: Italy, Greece, Macedonia, Bulgaria, Turkey, Ukraine (Crimea), Lebanon, Syria, Israel, Azerbaijan, Iran, Kazakhstan, Kyrgyzstan [Spassky \& Schnitnikow, 1937; Levy, 1996; Mikhailov, 1997; Guseinov et al., 2005; Helsdingen, 2010; Platnick, 2011]. Records from South of European part of Russia, cited in some catalogues [for example, Helsdingen, 2010], based on misidentifications [A.V. Ponomarev, personal communication]. Crimea is probably the most northernmost locality of this species (as well as record from Kazakhstan by Spassky \& Schnitnikow [1937 — sub A. taurica]).

PHENOLOGY. In Crimea $\sigma^{7} \sigma^{\top}-$ VI-VIII, O+ VI-XI, the peak of activity is in July. In Israel activity of adults starts a month earlier than in Crimea: $\sigma^{7} \sigma^{7}-\mathrm{V}-$ VI, + - — V-X [Levy, 1996]. In Lebanon also activity of adults starts a month earlier than in Crimea, but females have two month longer period of activity than in Crimea: $\sigma^{7} \sigma^{\Upsilon}-\mathrm{V}-\mathrm{VII},++$ - - V-I [Assi, 1990].

\section{Agelena labyrinthica (Clerck, 1757)}

Figs 4-6, 10-12, 16-18, 21-22, 25-26, 28.

A. l.: Brignoli, 1976: 563, f. 42 ().

A. l.: de Blauwe, 1980: 13, f. 20-25 (O'P)

A. l.: Levy, 1996: 87, f. 9-13 (O'T).

For a complete list of references see Platnick [2011]

RECORDS FROM CRIMEA. Kroneberg, 1875; Thorell, 1875a; Spassky, 1927; Charitonov, 1932; Bragina, 1984; Mikhailov, 1997; Kovblyuk, 2004ab.

MATERIAL. UKRAINE. Crimea: Simferopol Distr.: 2 우 (TNU-2162/1), NE slope of Chatyr-Dagh Mt., mountain steppe, 17.07.2000, M.K.; 1 O', 1 + (TNU-1915/13, 1931/6), Chatyr-Dagh Mt., Spiraea hypericifolia, pitfalls, 17-29.07.2000, M.K.; 1 क (TNU-2054/2), Krasnolesye Vill., 15-17.07.2005, M. Kadyev; 2 $\mathrm{O}^{\top} \mathrm{O}^{\top}, 2$ 우 (TNU), Dolgorukovskaya Yaila Mt., Kalan-Bair, 29.06.4.07.2010, M.K.; Yalta Distr.: 1 (TNU-2489/1), Nikitskaya Yaila Mt., mountain steppe, 17.08.2001, M.K.

COMPARATIVE MATERIAL. ABKHAZIA. Ochamchyra Distr.: $10^{7}, 1$ (TNU-2653/26), left bank of Kodor River, AtaraArmyanskaya Vill., wood, 24.07.-4.08.2008, M.K.; Sukhum Distr.: $1 \mathrm{O}^{7}$ (TNU-2644/15), Gumysta Reserve, East Gumysta River, kordon Tsymur, wood, 26-29.07.2008, M.K.; 2 우 (TNU-2645/1), ZemoBirtskha Vill., 30.07.2008, M.K. UKRAINE. Cherkasy Area: $10^{7}$ (TNU), Kanev Distr., Kanev Reserve, Mar'yna gora, meadow, 10.06.2009, E.N. Singaevsky; Donetsk Area: $1 \mathrm{O}^{7}$ (TNU), Donetsk, Peski Vill., 28.07.-4.08.2008, E.V. Prokopenko; $20^{7} \sigma^{7}, 2$ 우 (TNU-16.794), Donetsk, no data, E.V. Prokopenko; 3 O $^{7} 0^{7}, 1$ ㅇ (TNU-22.793), Krasnolymansky Distr., Torskoe Vill., no data, E.V. Prokopenko; Kyiv Area: 1 † (TNU-13), Tetiv Distr., Tetiv, Ros' River coast, 26.07.2006, A.A. Nadolny; 1 (TNU-2), same place, 2.08.2006, A.A. Nadolny; Lugansk Area: 1 (TNU), StanichnoLuganskyi Distr., "Pridontsovskaya poyma" - subdivision of Lugansk Nature Reserve, meadow, 15.09.2001, E.V. Prokopenko.

DIAGNOSIS. See the $A$. orientalis diagnosis.

DESCRIPTION. Males $(\mathrm{n}=6)$ and females $(\mathrm{n}=10)$. Measurements $\left(\mathrm{O}^{7} / 9\right)$ : total length 8.0-10.8 (9.65)/ 9.6-15.5 (11.9); carapace 4.4-5.4 (4.9) / 4.5-6.4 (5.4) long, 3.2-4.0 (3.6) / 3.0-4.0 (3.6) wide. Diameters of eyes and distances between them: AM 0.24-0.30 (0.27)

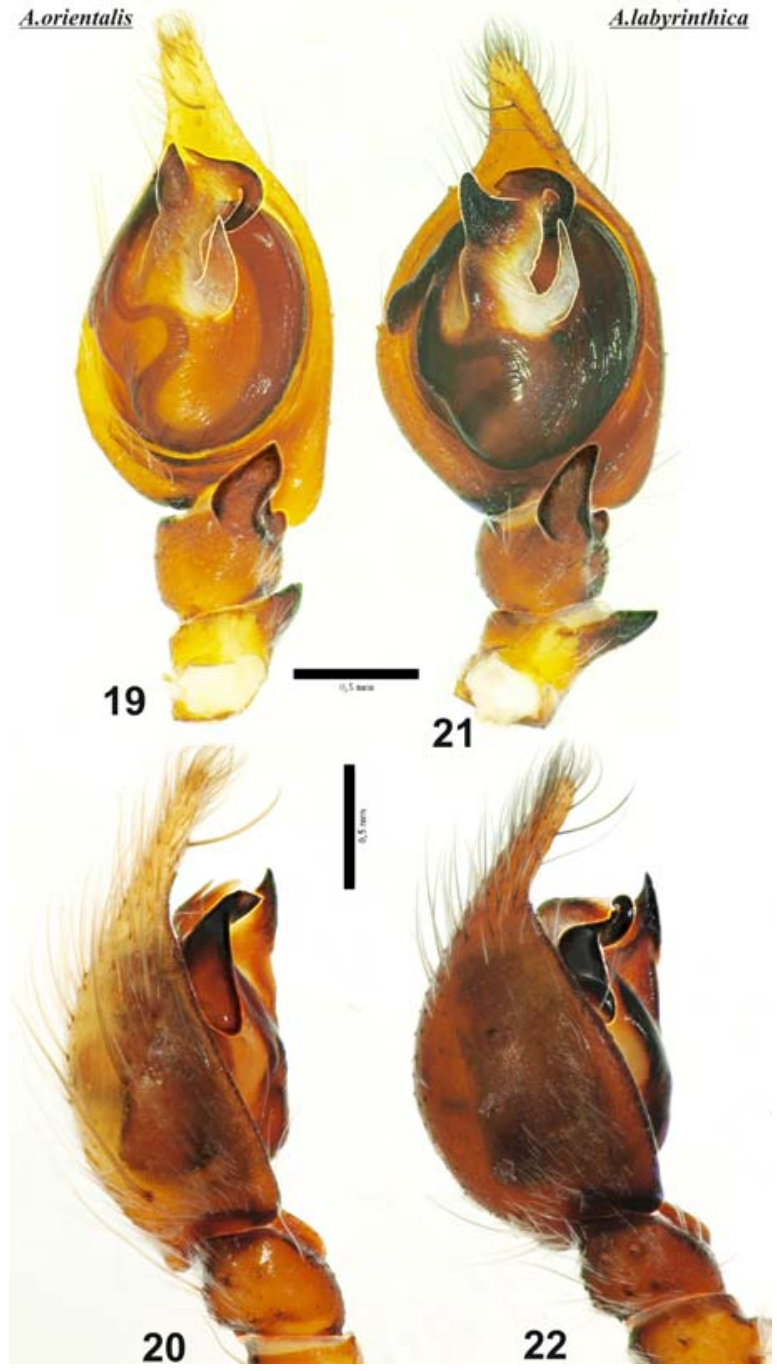

Figs 19-22. Male palps of Agelena orientalis (19-20) and A.labyrinthica (21-22): 19, 21 — ventral view; 20, 22 - prolateral view. Scale bars $0.5 \mathrm{~mm}$.

Рис. 19-22. Пальпы самцов Agelena orientalis (19-20) и A.labyrinthica (21-22): 19, 21 - вентрально; 20, 22 - пролатерально. Масштаб 0,5 мм.

/ 0.24-0.3 (0.28), AL 0.22-0.27 (0.25) / 0.22-0.28 (0.26), PM 0.20-0.24 (0.22) / 0.21-0.24 (0.22), PL $0.21-0.26(0.22) / 0.20-0.27$ (0.24), AM-AM 0.10$0.12(0.10) / 0.08-0.12(0.10)$, AM-AL 0.08-0.09 (0.08) / 0.06-0.10 (0.09), PM-PM 0.20-0.22 (0.21) / 0.18-0.24 (0.22), PM-PL 0.20-0.22 (0.21) / 0.20 0.27 (0.23), AM-PM 0.20-0.24 (0.22) / 0.20-0.27 (0.24), AL-PL 0.04-0.06 (0.06) / 0.04-0.09 (0.06). Distances between anterior eyes and margin of clypeus: AM-clypeus 0.51-0.69 (0.59) / 0.50-0.70 (0.60), ALclypeus $0.30-0.44(0.37) / 0.30-0.40(0.40)$. Length of palp segments (male/female): femur 1.5-2.0 (1.8) / $1.6-2.1(2.0)$, patella $0.5-0.7(0.6) / 0.7-0.9(0.8)$, tibia $0.4-0.5(0.4) / 0.8-1.0(0.9)$, tarsus $1.9-2.3(2.2) / 1.8-$ 2.2 (2.0). Length of leg segments (male/female) as in Table 2 . 


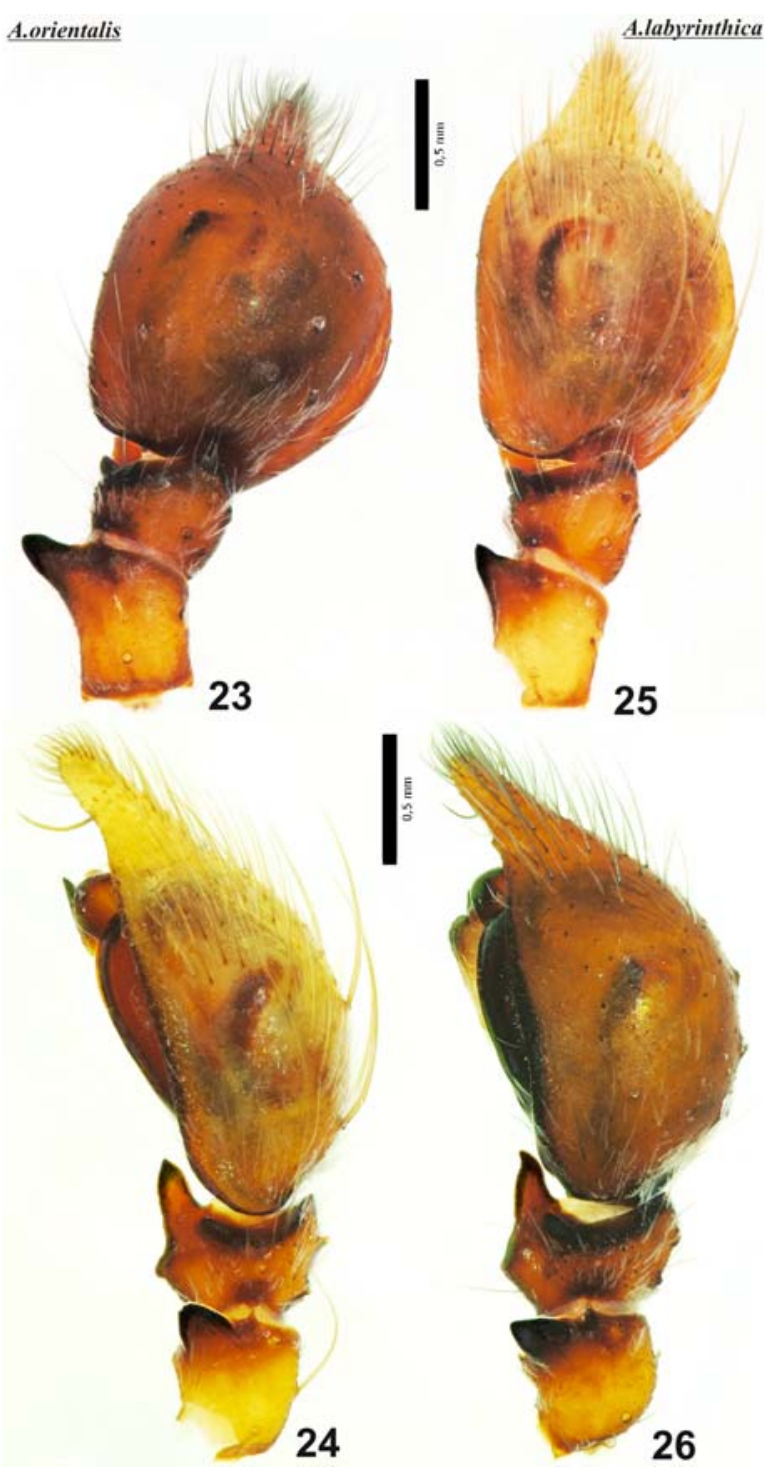

Figs 23-26. Male palps of Agelena orientalis (23-24) and A.labyrinthica (25-26): 23, 25 - dorsal view; 24, 26 - retrolateral view. Scale bars $0.5 \mathrm{~mm}$

Рис. 23-26. Пальпы самцов Agelena orientalis (23-24) и A.labyrinthica (25-26): 23, 25 - дорсально; 24, 26 - ретролатерально. Масштаб 0,5 мм.

Cheliceral teeth $\left(\sigma^{x} / 9\right)$ : anterior $-3 / 3$ or 4 (2 of 10 females have one chelicera with 3 teeth and one with 4 teeth); posterior -3 / 3 or 4 ( 2 of 10 females have one chelicera with 3 teeth and one with 4 teeth).

Coloration yellow with peculiar dorsal pattern on abdomen, as in $A$. orientalis.

Male palp: Figs 4-6, 10-12, 21-22, 25-26; epigyne: Figs 16-18, 28.

TYPE LOCALITY. Clerck [1757] described this species from Sweden without an exact locality. Neotype from Belgium (so it is the type locality) was designated by de Blauwe [1980].

DISTRIBUTION. Trans-Palaearctic nemoral range: from Portugal and Spain east to Maritime Province of

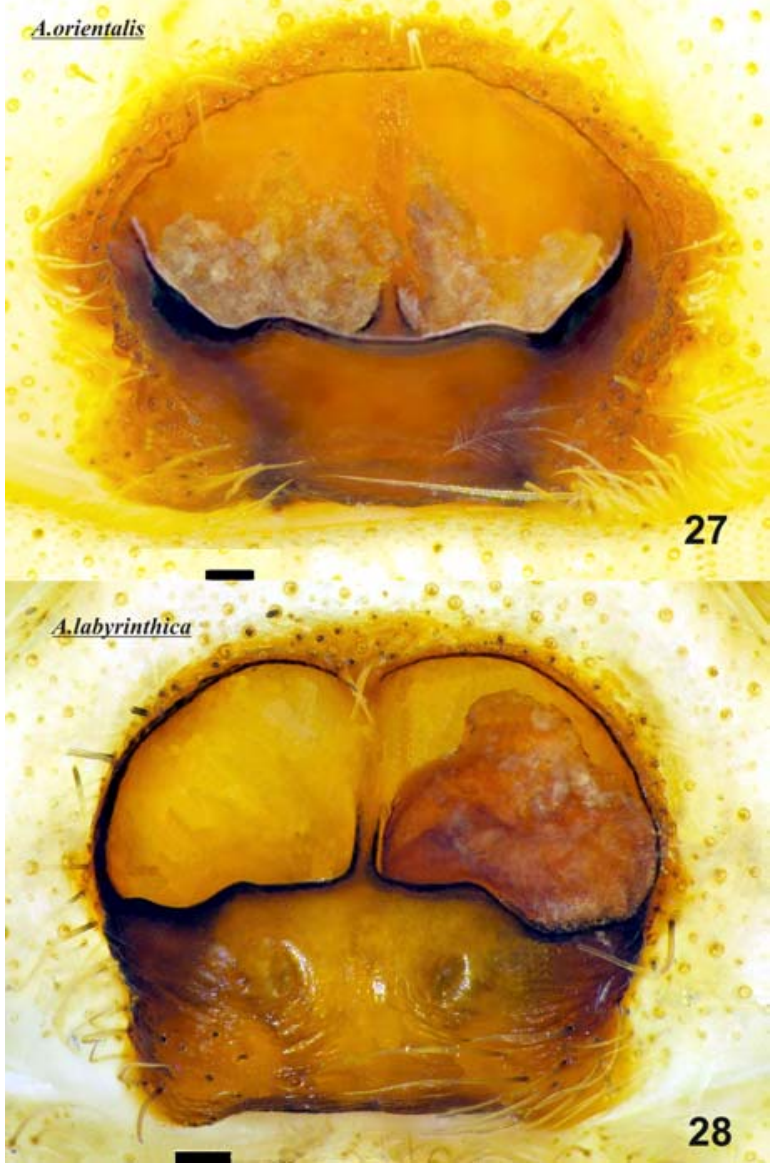

Figs 27-28. Epigynes of Agelena orientalis (27) and A.labyrinthica (28), ventral view. Scale bars $0.1 \mathrm{~mm}$.

Рис. 27-28. Эпигины Agelena orientalis (27) и A.labyrinthica (28), вентрально. Масштаб 0,1 мм.

Russia, Korea and Japan; and from Scandinavia south to Sardinia, Sicily, Crete and China [Mikhailov, 1997; Marusik et al., 2000; Helsdingen, 2010; Platnick, 2011].

PHENOLOGY. In Crimea $\bigcirc^{7} \sigma^{\top}-$ VI-VII, VI-VIII, peak of activity in July. In England $\sigma^{7} \sigma^{7}$ VI-VIII, $+q_{+}-\mathrm{VI}-\mathrm{X}$, the peak of activity is in August, a month later than in Crimea [Harvey et al., 2002]. In Czech Republic adults in VII-IX [Miller, 1971], a month later than in Crimea.

\section{Spatial distribution}

A. orientalis and A. labyrinthica were found in all Crimean landscape (physical-geographic) zones. In Crimea there are seven major landscape zones: 1 semi-desert steppe and saline lands; 2 - true steppe; 3 - premontane forest steppe; 4 - forests of the northern slope of Crimean mountains; 5 - mountain meadows and steppes; 6 - forests of the southern slope of Crimean mountains; 7 - sub-Mediterranean vegetation of the Southern Coast of Crimea. Landscape distribution of $A$. orientalis and A. labyrinthica is shown in Table 3 and on Map 1. 


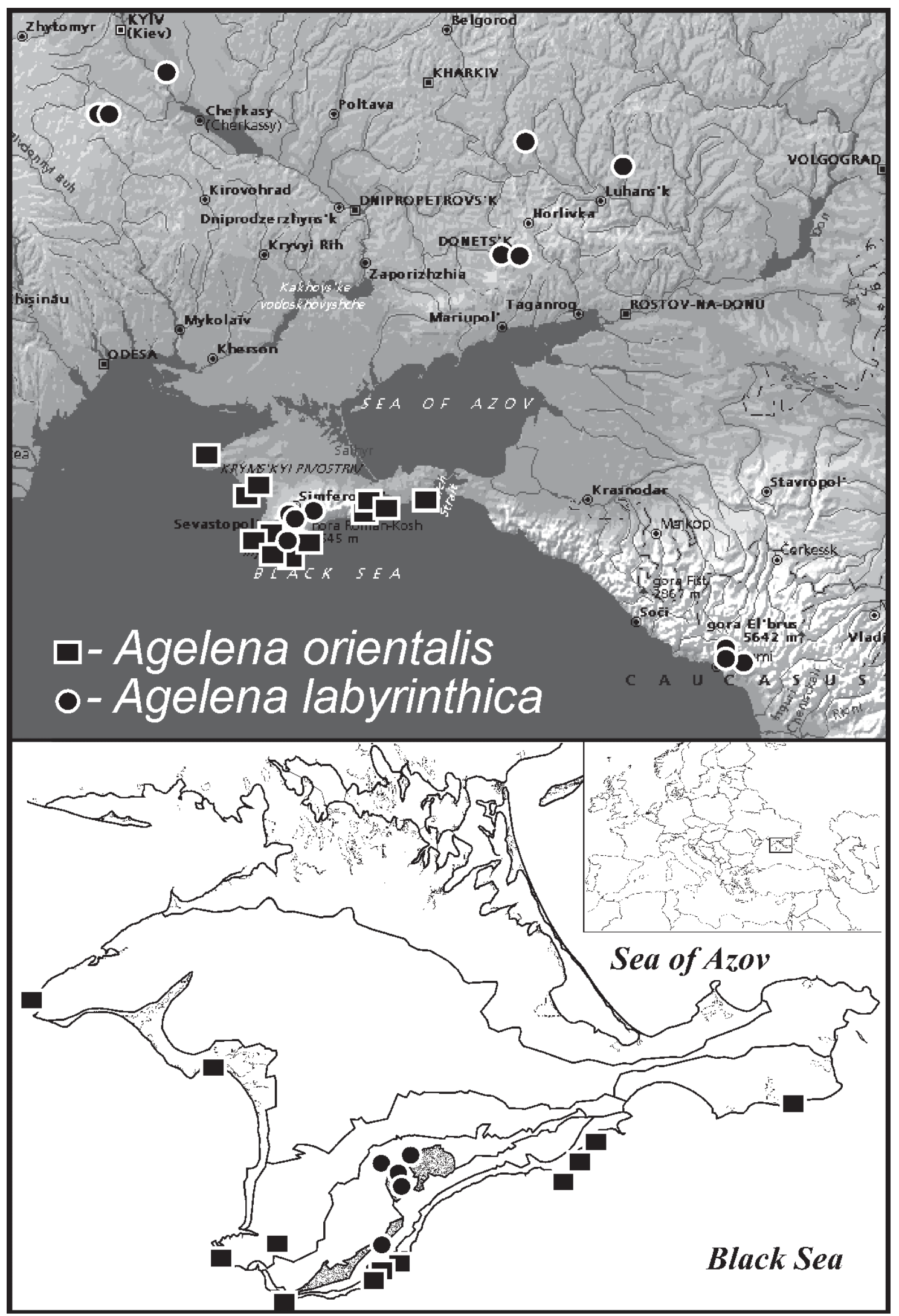

Map 1. Localities of studied specimens of Agelena labyrinthica and A. orientalis.

Карта 1. Места сбора изученных экземпляров Agelena labyrinthica и A. orientalis. 
Table 3. Distribution of Agelena orientalis and A. labyrinthica in the landscape zones of Crimea. Таблица 3. Ландшафтное распространение Agelena orientalis and A. labyrinthica в Крыму.

\begin{tabular}{|l|c|c|}
\hline \multicolumn{1}{|c|}{ Landscape zone } & A. orientalis & A. labyrinthica \\
\hline Semi-desert steppe and saline lands & + & - \\
\hline True steppe & + & - \\
\hline Premontane forest steppe & + & + \\
\hline Forests of the northern slope & - & + \\
\hline Mountain meadows and yaila steppes & - & - \\
\hline Forests of the southern slope & + & - \\
\hline Sub-mediterranean area of the southern coast & + & \\
\hline
\end{tabular}

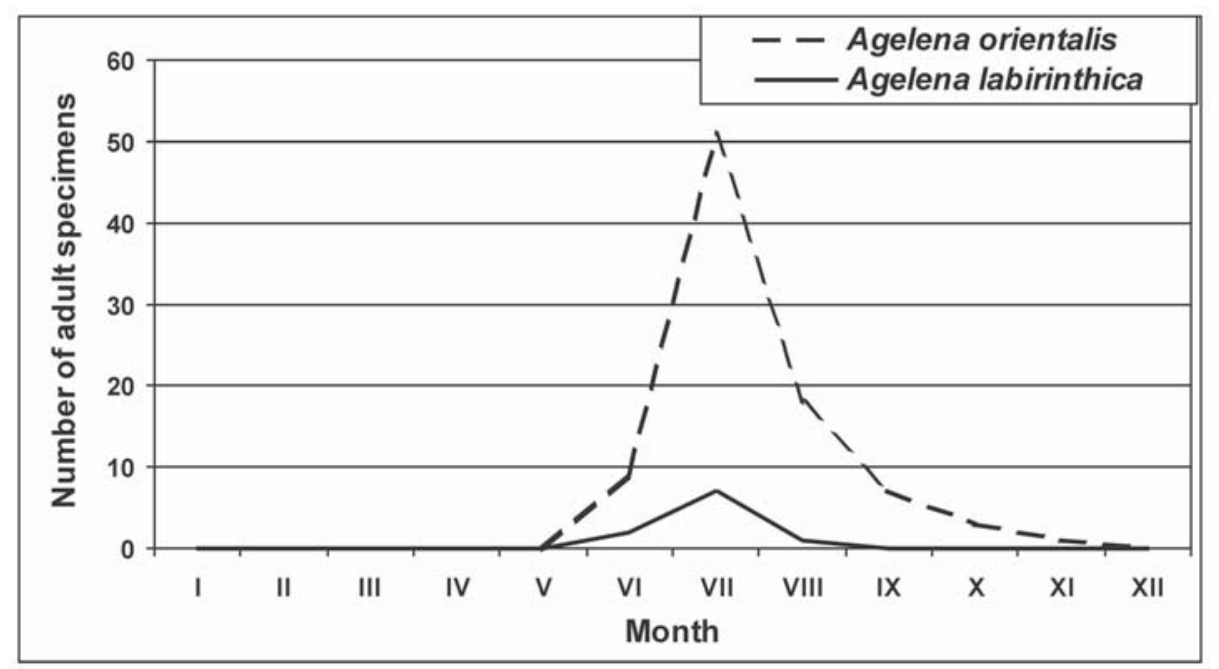

Fig. 29. Comparative phenology of Agelena orientalis and A. labyrinthica in the Crimea, based on the specimens collected.

Рис. 29. Сравнительная фенология Agelena orientalis и A. labyrinthica в Крыму по материалам коллекции.

A. orientalis was found in saline lands, semi-desert steppe, true steppe, forest-steppe and in sub-Mediterranean areas of southern Crimea. A. labyrinthica is recorded only from Crimean mountains (grasslands in forests of the northern slope; mountain meadows and steppes).

In conclusion, distribution of $A$. labyrinthica in the Crimea is limited by elevated mountain parts of peninsula only, but $A$. orientalis occurs around the Crimean Mountains. Similar distribution pattern for both species is reported from Azerbaijan [Guseinov et al., 2005].

\section{Seasonal dynamic of activity}

Seasonal activities of $A$. orientalis and $A$. labyrinthica in Crimea are similar. Adults of both species became active in June, and a single peak of activity is in July. Seasonal dynamics of adults' activity show on Fig 29.

ACKNOWLEDGMENTS. Authors provide many thanks to R.S. Dbar (Sukhum, Abkhazia) for a lot of logistic help in expeditions in Abkhazia in 2008-2009 and 2011. M.K. sincerely thanks Yu.M. Marusik (Magadan, Russia) and Seppo Koponen (Turku, Finland) who arranged the stay in Turku and provided lab equipment (digital camera attached to mi- croscope). We also thank D.V. Gluhov (Simferopol), M. Kadyev (Krasnolesye Vill., Simferopol), M.A. Kovaleva (Simferopol), O.V. Kukushkin (Karadag Nature Reserve), A.A. Nadolny (Simferopol), E.V. Prokopenko (Donetsk) and E.N. Singaevsky (Kyiv) for providing us some spiders collected from Crimea and continental Ukraine. Authors sincerely thank A.V. Ponomarev (Rostov-on-Don, Russia) for some useful remarks, comments and corrections. We thank P.E. Gol'din (Simferopol) for improving the English of the earlier draft. English of the final draft was checked by R. Leech (Edmonton, Canada).

This work of M.K. was supported in part by the Karadag Nature Reserve.

\section{References}

Assi F. 1990. Quelques donnees ecologiques et phenologiques sur 1'araignee Agelena orientalis C.L. Koch (Araneae, Agelenidae) // Revue arachnologique. T.9. Fasc.7. P.79-82.

Blauwe R., de. 1980. Revision de la famille des Agelenidae (Araneae) habitant la region mediterraneene (3e partie) // Bull. Inst. r. Sci. nat. Belg. Vol.52. No. 11. P.1-28.

Bragina V.A. 1984. [Spiders fauna of Karadagh] // AN USSR. Institut biologii yuzhnykh morei im. A.O. Kovalevskogo. Karadagskoe otdelenie. Karadagskyi gosudarstvennyi zapovednik AN USSR. Letopis' prirody. O.1. Kniga.1. Chast'4. P.64-68 [in Russian]. 
Brignoli P.M. 1976. Ragni di Grecia IX. Specie nuove o interessanti delle famiglie Leptonetidae, Dysderidae, Pholcidae ed Agelenidae (Araneae) // Revue suisse Zool. T.83. Fasc.3. P.539 578.

Charitonov D.E. 1932. Katalog der russischen spinnen. AN SSSR. Leningrad: Izdatelstvo AN SSSR. 206 p. [in Russian and German].

Charitonov D.E. 1936. Nachtrag zum katalog der russischen spinnen // Uchenie zapiski Permskogo universiteta. T.2. Vyp.1. S.167225 [in Russian and German].

Clerck C. 1757. Svenska spindlar. Aranei Svecici. Stockholmiae. $154 \mathrm{p}$.

Fausek V.A. 1909. [Guanine deposits in spiders (Araneae)] // Zapisky imperatorskoi akademii nauk, St-Petersburg. Ser.8. T.24. Vyp.3. P.1-58 [in Russian].

Guseinov E.F., Marusik Yu.M., Koponen S. 2005. Spiders (Arachnida: Aranei) of Azerbaijan. 5. Faunistic review of the funnel-web spiders (Agelenidae) with the description of new genus and species // Arthropoda Selecta. Vol.14. No.2. P.153177.

Harvey P.R., Nellist D.R., Telfer M.G. (eds.) 2002. Provisional atlas of British spiders (Arachnida, Araneae). Volumes $1 \& 2$. Huntington: Biological Records Centre. 406 p.

Helsdingen van P. 2010. Fauna Europaea: Araneae. Fauna Europaea version 2.4. Web Service available online at <http:// www.faunaeur.org $>$.

Kovblyuk M.M. 2002. [To question about endemism of Crimean spiders (Arachnida, Aranei)] // Zapovedniki Krima. Materialy II nauchnoi konferencii (25-26 April 2002). Simferopol. P.103109 [in Russian].

Kovblyuk M.M. 2004a. [Catalogue of the spiders (Arachnida, Aranei) of the Crimea] // Voprosy razvitiya Kryma. Nauchnoprakticheskiy I diskussionno-analiticheskiy sbornik. Vyp.15. Problemy inventarizatsii krymskoi bioty. Simferopol: TavriyaPlus. P.211-262 [in Russian].

Kovblyuk M.M. 2004b. [Preliminary results of spiders fauna and biotopic distribution of spiders in Karadag Nature Reserve study] // National Academy of Sciences of Ukraine. Karadag Nature Reserve. Annals. T.20 (2003). P.139-145 [in Russian].

Kovblyuk M.M., Kukushkin O.V. 2007. [Addition to the spiders check-list (Aranei) of Karadag] // Nationalnaya akademia nauk Ukrainy. Karadagskiy prirodniy zapovednik. Letopis' prirody. Simferopol: Sonat. T.22. P.207-210 [in Russian].

Kovblyuk M.M., Nadolny A.A., Gnelitsa V.A., Zhukovets E.M 2008a. [Spiders (Arachnida, Aranei) of the Martyan Cape
Reserve (Crimea, Ukraine)] // Caucasian entomological Bulletin. Vol.4. No.1. P.3-40 [in Russian, with English summary]. Kovblyuk M.M., Kukushkin O.V., Gnalitsa V.A., Nadolny A.A. 2008b. [Brief atlas of spiders (Arachnida, Aranei) of Karadag Nature Reserve]. Simpheropol: N.Orianda. 120 p. [in Russian].

Kroneberg A.I. 1875. [Reise in Turkestan von Alexis Fedtschenko] // Izvestiya imperatorskogo obshchestva lyubiteley estestvoznaniya, antropologii i etnographii. T.19. Vyp.3. P.I-IV, 1-55 [in Russian].

Levy G. 1996. The agelenid funnel-weaver family and the spider genus Cedicus in Israel (Araneae, Agelenidae and Cybaeidae) // Zoologica Scripta. Vol.25. No.2. P.85-122.

Marusik Yu.M., Logunov D.V., Koponen S. 2000. Spiders of Tuva, South Siberia. Magadan: IBPN FEB RAS. 252 p.

Mikhailov K.G. 1997. Catalogue of the spiders (Arachnida, Aranei) of the territories of the former Soviet Union. Moscow: Zoological Museum of the Moscow State University. 416 p.

Mikhailov K.G. 1998. Catalogue of the spiders (Arachnida, Aranei) of the territories of the former Soviet Union. Addendum 1. Moscow: KMK Scientific Press Ltd. 50 p.

Miller F. 1971. Pavouci - Araneida // Klíč zvířeny ČSSR. Praha. Díl.4. S.51-306.

Platnick N.I. 2011. The world spider catalog, version 11.5. American Museum of Natural History, online at http://research.amnh. org/iz/spiders/catalog.

Spassky S.A. 1927. [Contribution to the spider fauna of Crimea] // Izvestiya Donskogo Instituta selskogo khozyaistva i melioratsii. Vol.7. P.66-80 [in Russian].

Spassky S.A., Schnitnikow W.N. 1937. [Materials to the spider fauna of Kazakhstan] // Materialy po vreditelyam zhivotnovodstva i faune preimuschestvenno Yuzhnogo Kazakhstana. Trudy Kazakhskogo filiala AN SSSR. M.-L.: Izdatelstvo AN SSSR. Vyp.2. P.264-300 [in Russian with German summary].

Thorell T. 1875a. Verzeichniss sudrussischer Spinnen // Horae Societatis entomologicae Rossicae. T.11. P.39-122.

Thorell T. 1875b. Descriptions of several European and North African spiders // Kongl. Svenska Vetenskaps-Akademiens Handlingar. Bd.13. No.5. P.1-203.

Tyshchenko V.P. 1971. [An identification guide to the spiders of the European part of the USSR]. Leningrad: Nauka. 281 p. [in Russian]. 